\title{
Efek Sitotoksik, Antiproliferatif dan Apoptosis Serum Tikus (Rattus novergicus Berkenhout, 1769) diberi Serbuk Tokek (Gekko gecko L.) Per Oral Terhadap Sel WiDr
}

\author{
TRIANA NURYASTUTI ${ }^{1}$, RARASTOETI PRATIWI $^{2}$, NYOMAN PUNIAWATI SOESILO $^{2}$ \\ ${ }^{1}$ Jurusan Pendidikan Jasmani, Kesehatan \& Rekreasi, Universitas Bumi Hijrah Tidore \\ JL. Lintas Halmahera-Sofifi, Oba Utara, Kota Tidore, Kepulauan Maluku Utara. 97852 \\ ${ }^{2}$ Fakultas Biologi, Universitas Gadjah Mada \\ Jl. Teknika Selatan, Sekip Utara, Yogyakarta. 55281 \\ Email: triananuryastuti@gmail.com
}

\begin{abstract}
Gecko is one of the reptiles are used as traditional Chinese medicine which has been reported as antitumor capabilities. The purpose of this study was to determine the cytotoxic effect of rat serum that treated with gecko powder and its ability to inhibit proliferation and stimulate apoptosis of WiDr cells. Gecko powder the treated in vivo in the rat (Rattus novergicus) SD female. Twelve mice treated with powder gecko at a dose of $9 \mathrm{~g} / \mathrm{kg}$ body weight per day. Then the rat blood serum on the in vitro treated in WiDr cells. Cytotoxicity test using the MTT method. Observation of the proliferation kinetics using doubling time test. Then apoptosis test performed by the doublestaining method. Cytotoxicity assay results showed that the powder is toxic to the gecko cell WiDr. In the cytotoxicity test showed $\mathrm{IC}_{50}$ rat serum with gecko powder body parts obtained at a concentration of $7,914 \%$. The observation of cell proliferation kinetics demonstrated rat serum with gecko powder body parts most effective in inhibiting the proliferation of WiDr cells Data apoptotic WiDr cells showed the rat serum with gecko powder effective agency in promoting apoptosis. Rat serum with treat gecko powders bodies part are toxic and can inhibit proliferation and stimulate apoptosis of WiDr cells.
\end{abstract}

Keywords: antiproliferasi, apoptosis, cytotoxicity, powder gecko, WiDr cells

\section{INTISARI}

Tokek merupakan salah satu reptil yang digunakan sebagai obat tradisional China yang dilaporkan mempunyai kemampuan sebagai antitumor. Tujuan penelitian ini adalah untuk mengetahui efek sitotoksik serbuk tokek dan kemampuannya dalam menghambat proliferasi serta memacu apoptosis sel WiDr. Serbuk tokek diperlakukan secara in vivo pada tikus putih (Rattus novergicus) SD betina. Dua belas tikus diperlakukan dengan serbuk tokek dengan dosis $9 \mathrm{~g} / \mathrm{kg}$ per hari serta kontrol (plasebo) diberikan per oral 2 kali sehari. Serum darah tikus tersebut diujikan secara in vitro pada sel WiDr. Uji sitotoksisitas menggunakan metode MTT. Pengamatan kinetika proliferasi menggunakan uji doubling time Selanjutnya dilakukan uji apoptosis dengan metode doublestaining. Hasil uji sitotoksisitas menunjukkan bahwa serum tikus dengan serbuk tokek bersifat toksik terhadap sel WiDr dengan $\mathrm{IC}_{50}$ diperoleh pada konsentrasi 7,914\%. Hasil pengamatan kinetika proliferasi sel menunjukkan serum tikus dengan serbuk tokek bagian badan paling efektif dalam menghambat proliferasi sel WiDr. Data apoptosis sel WiDr menunjukkan serum tikus dengan serbuk tokek dari bagian badan paling efektif dalam memacu apoptosis. Serum tikus yang diperlakukan dengan serbuk tokek bagian badan bersifat toksik dan mampu menghambat proliferasi serta memacu apoptosis sel WiDr.

Kata kunci: antiproliferasi, apoptosis, sitotoksisitas, serbuk tokek, sel WiDr

\section{PENDAHULUAN}

Kanker kolon merupakan salah satu penyakit kanker yang memiliki prevalensi Copyright $\left({ }_{0} 2018\right.$ Universitas Islam Negeri Alauddin Makassar. This is an open access article under the CC BY license (https://creativecommons.org/licenses/by/4.0/) cukup tinggi di dunia. Satu di antara 26 wanita dan 1 di antara 17 pria di Australia terjangkit penyakit kanker kolon rektal (AIHW, 2004). 
Kanker kolon merupakan salah satu kanker saluran pencernaan yang banyak dialami masyarakat yang mempunyai kebiasaan mengonsumsi makanan dengan diet tinggi lemak dan rendah serat serta kalsium. Pengobatan kanker secara medis yang selama ini dilakukan adalah dengan mengambil kanker melalui pembedahan, kemoterapi atau radioterapi (Saputra, 2003). Kemoterapi yang telah tersedia saat ini belum sepenuhnya mengatasi kanker. Secara klinis efektivitas obat antikanker belum memuaskan karena selektivitasnya rendah.

Keanekaragaman hayati di Indonesia sangat mendukung untuk pengembangan penggunaan ramuan obat alami dari hewan sebagai obat untuk kanker. Ramuan obat alami dengan menggunakan hewan masih belum dikembangkan secara optimal, salah satu diantaranya adalah tokek. Penelitian yang telah dilakukan di China menunjukkan bahwa zat aktif pada tokek mempunyai kemampuan sebagai antikanker terutama kanker saluran pencernaan (Liu et al., 2008).

Penelitian ini menggunakan cell line kanker kolon karena terdapat keterkaitan dengan penelitian sebelumnya bahwa tokek mempunyai kemampuan sebagai antikanker khususnya pada saluran pencernaan.Menurut Liu et al., (2008) bubuk tokek dapat menghambat proliferasi dan memacu apoptosis sel tumor esophagus secara in vitro menggunakan serum tikus yang telah diperlakukan dengan bubuk tokek per oral.Penelitian ini dilakukan untuk mengetahui efek sitotoksik serbuk tokek dari bagian tubuh yang berbeda dan kemampuannya dalam menghambat proliferasi serta memacu apoptosis sel kanker kolon WiDr.

\section{METODOLOGI}

\section{Pembuatan serbuk tokek (Gekko gecko L.)}

Tokek yang digunakan dalam bentuk sediaan kering Setelah itu dihaluskan untuk dibuat serbuk dengan cara digiling sampai diperoleh serbuk tokek yang halus. Masingmasing bagian tubuh tokek yang telah dihaluskan tersebut kemudian disimpan secara terpisah dalam botol tertutup dan diberi label agar tetap steril dan tidak tertukar dengan bagian tubuh tokek yang lainnya.

\section{Preparasi serum darah tikus yang diberi perlakuan serbuk tokek}

Dua belas tikus putih betina galur SD (umur 2 bulan) secara acak dibagi dalam 4 kelompok perlakuan yaitu kelompok kontrol (plasebo), kelompok P1 (serbuk tokek kepala), kelompok P2 (serbuk tokek badan), dan kelompok P3 (serbuk tokek ekor) dengan masing-masing kelompok perlakuan 3 ekor tikus. Masing-masing kelompok diberi perlakuan dengan serbuk tokek dengan dosis 9 $\mathrm{g} / \mathrm{kg}$ per hari sebanyak dua kali sehari per oral. Pada kelompok kontrol (plasebo) diberi perlakuan dengan akuades. Darah diambil pada $h+7$ setelah perlakuan kemudian darah dari masing-masing perlakuan tersebut disentrifugasi untuk memisahkan serum darahnya. Serum darah yang diperoleh kemudian disimpan dalam lemari pendingin pada suhu $-20^{\circ} \mathrm{C}$ sebelum diperlakukan untuk uji selanjutnya.

\section{Kultur sel kolon WiDr Uji Sitotoksik}

Suspensi selkanker kolon WiDr sebanyak $100 \mu \mathrm{l}$ dengan kepadatan $1 \times 10^{4} \mathrm{sel} / 100 \mu \mathrm{l}$ media kultur ditanam ke dalam96 wellplate dan diinkubasi selama 24 jam di dalam inkubator dengan $5 \% \mathrm{CO}_{2}$ dan $95 \% \mathrm{O}_{2}$. Setelah diinkubasi, ke dalam sumuran dimasukkan 100 $\mu \mathrm{l}$ sampel uji dengan 5 seri konsentrasi. Sebagai kontrol positif ditambahkan $100 \mu \mathrm{l}$ doxorubicindengan 5 seri konsentrasi yaitu $100 ; 50 ; 25 ; 12,5 ; 6,25 \mu \mathrm{g} / \mathrm{ml}$ kedalam sumuran yang berisi $100 \mu \mathrm{l}$ suspensi sel. Sebagai kontrol sel ditambahkan $100 \mu 1$ media kultur ke dalam sumuran yang berisi $100 \mu \mathrm{l}$ suspensi sel, dan sebagai kontrol media ditambahkan $100 \mu \mathrm{l}$ medium kultur lengkap kemudian diinkubasi selama 24 jam dalam inkubator dengan $5 \% \mathrm{CO}_{2}$ dan $95 \% \mathrm{O}_{2}$. Pada akhir inkubasi media kultur dibuang lalu dicuci dengan PBS kemudian ditambahkan $110 \mu \mathrm{l}$ larutan MTT, kemudian sel diinkubasi selama 3-4 jam. Reaksi MTT dihentikan dengan penambahan reagen stopper $10 \%$ SDS $100 \mu$ l. Microwell plate berisi suspensi sel dishaker \pm 5 menit kemudian dibungkus dengan aluminium foil dan diinkubasi selama 1 malam 
pada suhu kamar. Sel yang hidup akanbereaksi dengan MTT membentuk warna ungu. Hasil pengujian dibaca dengan ELISA reader pada panjang gelombang $595 \mathrm{~nm}$ (Mae et al., 2000). Uji Kinetika Proliferasi sel

Seratus $\mu 1$ suspensi yang berisi sel kanker kolon WiDr dalam media kultur lengkap yang mengandung $1 \times 10^{4}$ sel dimasukkan ke dalam masing-masing 96 wellplate dan diinkubasi selama 24 jam pada suhu $37^{\circ} \mathrm{C}$ dalam inkubator $5 \% \mathrm{CO}_{2}$. Selanjutnya ditambahkan $100 \mu \mathrm{l}$ sampel uji dengan 5 seri konsentrasi kemudian inkubasi pada suhu $37^{\circ} \mathrm{C}$ dalam inkubator $5 \% \mathrm{CO}_{2}$ dilanjutkan dengan variasi waktu 0, 24, 48 dan 72 jam. Selanjutnya pada setiap akhir inkubasi media kultur dibuang dan dicuci dengan PBS, kemudian ditambah $110 \mu \mathrm{l}$ larutan MTT ke dalam setiap sumuran dan diinkubasi dalam inkubator $5 \% \mathrm{CO}_{2}$ pada suhu $37^{\circ} \mathrm{C}$ selama 3-4 jam sampai terbentuk formazan. Reaksi MTT dihentikan dengan menambahkan $100 \mu$ stopper $10 \%$ SDS ke dalam setiap well untuk melarutkan kristal purple formazan. Selanjutnya dishaker \pm 5 menit dan dibungkus rapat dengan aluminium foil dan diinkubasi selama 1 malam pada suhu kamar. Sel yang masih hidup bereaksi dengan MTT membentuk warna ungu. Absorbansi dibaca dengan ELISA reader pada panjang gelombang ( $\lambda$ ) $595 \mathrm{~nm}$ (Meiyanto, 2008).

\section{Pengamatan Apoptosis}

Sel kanker kolon WiDr ditanam pada coverslips yang dimasukan dalam 24 wellplate sehingga diperoleh kepadatan $3 \times 10^{4}$ sel/sumuran dan diinkubasi sampai 50-60\% konfluen. Setelah itu diinkubasi dengan ditambahkan sampel uji serum darah tikus yang telah diperlakukan dengan serbuk tokek dari empat bagian tubuh yang berbeda dengan variasi konsentrasi yaitu pada $\mathrm{LC}_{50}$ dan 2 konsentrasi dibawah $\mathrm{LC}_{50}$ dibiarkan selama 24 jam. Media dibuang dengan pipet pasteur kemudian dicuci dengan PBS. Cover slip yang memuat sel diangkat, diletakan di atas object glass dan ditambahkan $10 \mu \mathrm{L}$ Working Solution etidium bromida/ akridin oranye kemudian didiamkan selama 5 menit. Sel segera diamati di bawah mikroskop flouresens (Zeiss MC 80). Sel hidup berfluoresensi hijau dengan akridin oranye dan sel mati berfluoresensi oranye dengan etidium bromida (Meiyanto, 2008).

\section{Analisis Data}

Data absorbansi yang diperoleh dari uji sitotoksik dan kinetika proliferasi sel dikonversi ke dalam persen sel hidup dan dianalisis dengan uji Anova dilanjutkan uji LSD menggunakan SPSS 17 untuk mengetahui signifikansi perbedaan antara kelompok kontrol dengan kelompok perlakuan. Rumus persen sel hidup dihitung menggunakan rumus:

$$
\text { Prosentase sel hidup }=\frac{(\text { Absorbansi perlakuan }- \text { Absorbansi kontrol media })}{(\text { Absorbansi kontrol sel }- \text { Absorbansi kontrol media })} \times 100 \%
$$

\section{HASIL}

Aktivitas antikanker serum tikus yang dipelakukan dengan serbuk tokek terhadap sel kanker kolon WiDr dapat dideteksi dengan menggunakan uji sitotoksisitas. Setelah inkubasi tampak adanya perubahan morfologi pada sel kolon WiDr. Sel yang hidup berwarna terang (berpendar) dan menempel pada dasar plate, sedangkan sel yang mati berwarna gelap (tidak berpendar) dan tidak menempel pada dasar plate. Beberapa kondisi sel kanker kolon WiDr setelah diberi perlakuan dengan serbuk tokek dapat dilihat pada Gambar 1. 


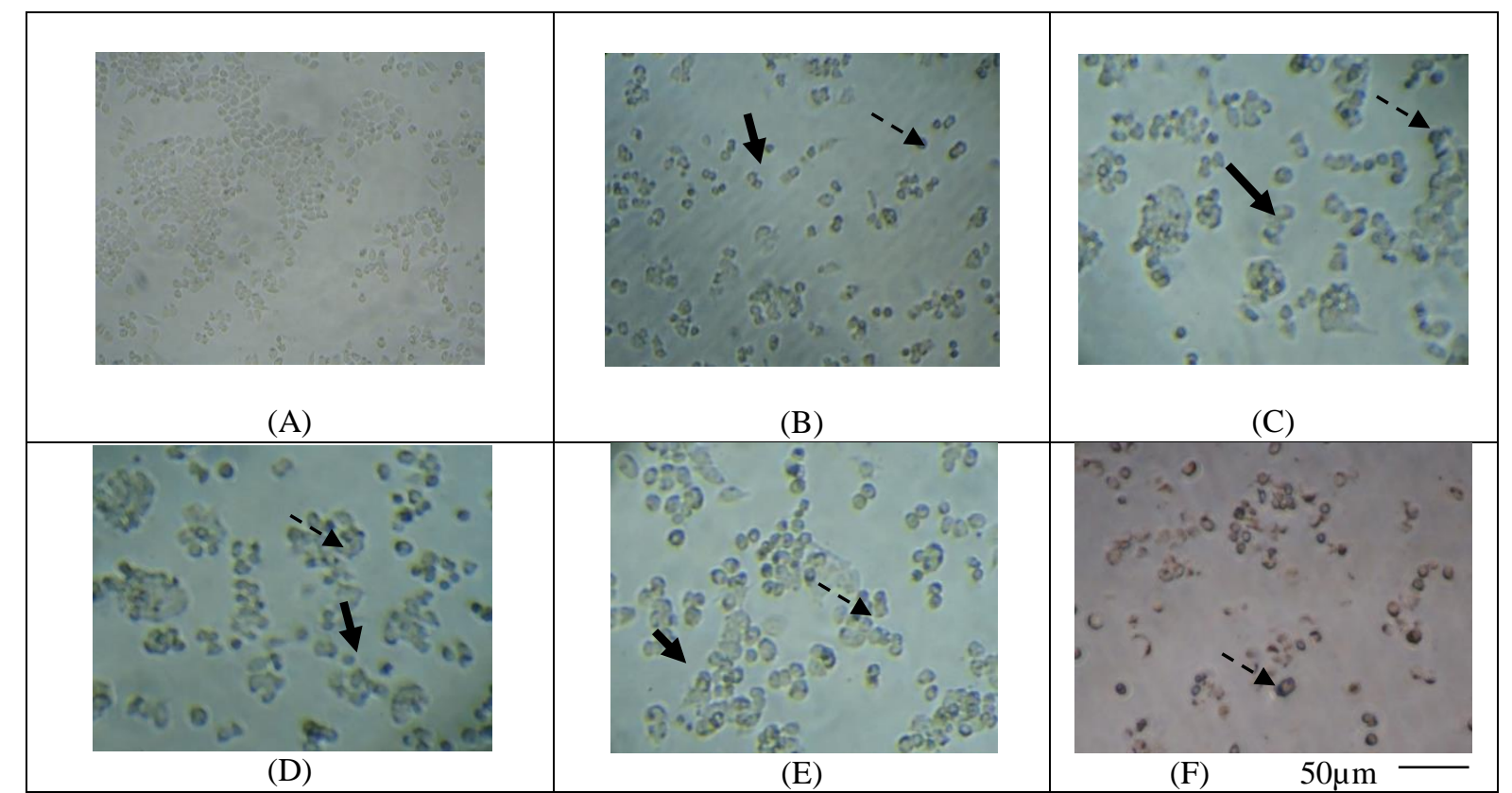

Gambar 1. Kondisi sel setelah perlakuan dengan sampel uji (A) kontrol sel, (B) kontrol serum, (C) perlakuan dengan sampel uji bagian kepala (P1), (D) perlakuan dengan sampel uji bagian badan (P2), (E) perlakuan dengan sampel uji bagian ekor+tungkai (P3), dan (F) perlakuan dengan doxorubicin (perbesaran mikroskop 10x10).

Keterangan:

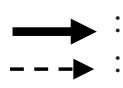

: sel hidup (terang/ berpendar) sel mati (gelap/ tidak berpendar)

\section{PEMBAHASAN}

Sitotoksisitas serum tikus yang diberi serbuk tokek terhadap sel kanker kolon WiDr. Gambar 1 menunjukkan berbagai kondisi sel WiDr setelah perlakuan dengan sampel uji. Kondisi sel yang mati ditunjukkan dengan warna yang gelap (tidak berpendar), sedangkan sel yang hidup terlihat terang (berpendar). Pada kondisi sel yang mati berwarna gelap dikerenakan pada sel ini kromatinnya memadat sehingga sel tampak gelap (tidak berpendar). Pada kontrol sel, tidak terlihat adanya sel yang mengalami kematian, sedangkan pada kelompok perlakuan secara keseluruhan memperlihatkan sel mengalami kematian. Pada kelompok kontrol serum juga menunjukkan kematian sel meskipun jumlahnya lebih sedikit dibandingkan pada kelompok perlakuan.

Diantara kelompok perlakuan, kelompok perlakuan serum dengan serbuk tokek bagian badan menunjukkan adanya kematian sel yang lebih banyak dibandingkan dengan perlakuan yang lainnya disusul kelompok perlakuan serum dengan serbuk tokek bagian kepala kemudian kelompok perlakuan serum dengan serbuk tokek bagian ekor+tungkai. Jumlah kematian sel WiDr selanjutnya disusul oleh kelompok perlakuan dengan serum dengan serbuk tokek bagian kepala. Sedangkan kematian sel WiDr terkecil adalah pada perlakuan serum dengan serbuk tokek bagian ekor+tungkai. Berdasarkan hipotesis yang diajukan diharapkan pada kelompok perlakuan ini mempunyai efek yang paling efektif dibandingkan dengan kelompok perlakuan yang lain karena kemampuan pada ekor untuk melakukan regenerasi pada bagian ekornya yang mengalami autotomi. Namun bagian ini menunjukkan hasil yang paling kecil dibandingkan dengan kelompok yang lain. Pada kelompok kontrol positif dengan pemberian doxorubicin kondisi sel terlihat banyak yang mati dan mengalami kerusakan (sel pecah). Hal ini menunjukkan bahwa doxorubicin merupakan obat kanker yang cukup toksik terhadap sel kanker kolon WiDr. Data persentase kematian sel akibat perlakuan dengan serum tikus dengan perlakuan serbuk tokek terhadap sel WiDr pada uji sitotoksik dapat dilihat pada Tabel 1 . 
Tabel 1. Persentase kematian sel WiDr dengan perlakuan serum tikus yang diperlakukan dengan serbuk tokek

\begin{tabular}{|c|c|c|}
\hline Kelompok Perlakuan & Konsentrasi serum (\%) & \% kematian sel \\
\hline \multirow{4}{*}{ Kontrol } & 50 & 0 \\
\hline & 25 & 0 \\
\hline & 12,5 & 21,24 \\
\hline & 6,25 & 27,00 \\
\hline \multirow{4}{*}{$\mathrm{P} 1$} & 50 & 0 \\
\hline & 25 & 0 \\
\hline & 12,5 & 0 \\
\hline & 6,25 & 15,48 \\
\hline \multirow{4}{*}{$\mathrm{P} 2$} & 50 & 0 \\
\hline & 25 & 0 \\
\hline & 12,5 & 77,22 \\
\hline & 6,25 & 57,29 \\
\hline \multirow{4}{*}{$\mathrm{P} 3$} & 50 & 0 \\
\hline & 25 & 0 \\
\hline & 12,5 & 0 \\
\hline & 6,25 & 0,17 \\
\hline
\end{tabular}

Keterangan: $\quad$ P1: serum tikus yang diberi perlakuan serbuk tokek bagian kepala

P2: serum tikus yang diberi perlakuan serbuk tokek bagian badan

P3: serum tikus yang diberi perlakuan serbuk tokek bagian ekor+tungkai

Tabel 1 menunjukkan bahwa pada berbagai kelompok perlakuan dengan serbuk tokek memperlihatkan adanya efek kematian pada sel kanker kolon WiDr. Kematian sel kanker kolon WiDr yang terbesar ditunjukkan pada kelompok perlakuan serbuk tokek bagian badan dengan kematian sebesar 77,22\% pada konsentrasi 12,5\%, sedangkan kelompok kontrol serum tanpa diberi perlakuan dengan serbuk tokek menyebabkan kematian $27,00 \%$ pada konsentrasi $6,25 \%$, kelompok bagian kepala $15,48 \%$ pada konsentrasi $6,25 \%$ dan kelompok bagian ekor+tungkai $0,17 \%$ pada konsentrasi 6,25\%. Hasil uji Anava $(\alpha=0,05)$ antar kelompok perlakuan tidak signifikan karena taraf signifikansi $\alpha>0,05$. Dari hasil tersebut menunjukkan bahwa pada konsentrasi sampel yang tinggi belum tentu menghambat atau mematikan sel, hal ini dikarenakan pada serum juga terkandung jenis protein tertentu yang berfungsi sebagai faktor pertumbuhan. Beberapa jenis protein pada serum juga terkandung pada Fetal Bovine Serum (FBS) salah satu bahan pada media kultur yaitu albumin, globulin dan fibronectin. Data kematian sel akibat perlakuan dengan doxorubicin pada uji sitotoksik dapat dilihat pada Tabel 2.

Tabel 2. Persentase kematian sel kanker kolon WiDr dengan perlakuan doxorubicin

\begin{tabular}{cc}
\hline Konsentrasi doxorubicin $(\boldsymbol{\mu g} / \mathbf{m l})$ & \% Kematian sel \\
\hline 50 & 100 \\
\hline 25 & 100 \\
\hline 12,5 & 96,66 \\
\hline 6,25 & 90,10 \\
\hline 3,125 & 65,69 \\
\hline 1,5625 & 41,62 \\
\hline
\end{tabular}

Tabel 2 menunjukkan persentase kematian sel kanker kolon WiDr akibat perlakuan dengan doxorubicin. Nilai $\mathrm{IC}_{50}$ dengan perlakuan doxorubicin ini adalah 2,295 $\mu \mathrm{g} / \mathrm{ml}$.

Hasil penelitian menunjukkan doxorubicin dapat menyebabkan kematian sel kanker kolon WiDr mulai pada konsentrasi $1,5625 \mu \mathrm{g} / \mathrm{ml}$ dengan persentase kematian $41,62 \%$ dan terus meningkat seiring dengan peningkatan konsentrasinya sampai pada $12,5 \%$ dengan persentase kematian sel sebesar $96,66 \%$. 
Efek serum tikus putih yang diberi perlakuan serbuk tokek terhadap proliferasi sel kanker kolon WiDr (uji doubling time). Untuk melihat toksisitas suatu senyawa terhadap sel kanker dapat diketahui juga dengan melihat penghambatan proliferasinya salah satunya dengan menggunakan uji doubling time. Uji doubling timepada penelitian ini dilakukan untuk mengetahui efek dari serum tikus putih yang diberi perlakuan dengan serbuk tokek terhadap proliferasi sel kanker kolon WiDr. Konsentrasi yang digunakan untuk uji doubling time ini adalah $50 \%, 25 \%, 12,5 \%$ dan $6,25 \%$ dengan waktu inkubasi $0,24,48$, dan 72 jam. Uji doubling time ini juga dilakukan dengan metode MTT, kemudian dihitung persentase sel hidup. Uji doubling time dilakukan pula pada kontrol positif yaitu doxorubicin untuk melihat efek antiproliferatif dari obat kanker doxorubicin tersebut terhadap sel kanker kolon WiDr. Konsentrasi doxorubicin yang digunakan untuk uji doubling timea dalah 6,25, $3,125,1,5625$, dan $0,78125 \mu \mathrm{g} / \mathrm{ml}$. Hasil uji doubling time dengan perlakuan serum tikus yang diberi perlakuan dengan serbuk tokek dapat dilihat pada Tabel 3 .

Tabel 3. Persentase jumlah sel kolon WiDr yang hidup dengan perlakuan serum tikus yang telah diperlakukan dengan serbuk tokek pada uji doubling time

\begin{tabular}{|c|c|c|c|c|c|}
\hline \multirow{3}{*}{$\begin{array}{l}\text { Kelompok } \\
\text { Perlakuan }\end{array}$} & \multirow{3}{*}{$\begin{array}{c}\text { Konsentrasi } \\
(\%)\end{array}$} & \multicolumn{4}{|c|}{ Jumlah sel hidup (\%) } \\
\hline & & \multicolumn{4}{|c|}{ Waktu inkubasi (jam) } \\
\hline & & $\mathbf{0}$ & 24 & 48 & 72 \\
\hline \multirow{4}{*}{ Kontrol } & 50 & 100 & 94,51 & 72,99 & 52,63 \\
\hline & 25 & 100 & 100 & 76,01 & 55,68 \\
\hline & 12,5 & 100 & 100 & 93,22 & 92,09 \\
\hline & 6,25 & 100 & 100 & 89,31 & 81,94 \\
\hline \multirow{4}{*}{ P1 } & 50 & 100 & 100 & 93,32 & 73,37 \\
\hline & 25 & 100 & 100 & 66,13 & 89,36 \\
\hline & 12,5 & 100 & 100 & 100 & 92,21 \\
\hline & 6,25 & 100 & 100 & 82,97 & 100 \\
\hline \multirow{4}{*}{$\mathrm{P} 2$} & 50 & 100 & 100 & 39,00 & 24,59 \\
\hline & 25 & 100 & 100 & 79,23 & 88,17 \\
\hline & 12,5 & 100 & 100 & 72,63 & 100 \\
\hline & 6,25 & 100 & 100 & 73,41 & 100 \\
\hline \multirow{4}{*}{ P3 } & 50 & 100 & 100 & 76,37 & 46,12 \\
\hline & 25 & 100 & 100 & 100 & 90,43 \\
\hline & 12,5 & 100 & 100 & 82,30 & 99,63 \\
\hline & 6,25 & 100 & 100 & 100 & 100 \\
\hline & $\begin{array}{l}\text { tikus yang } \\
\text { tikus yang }\end{array}$ & $\begin{array}{l}\text { kuan } \mathrm{s} \\
\text { kuan } \mathrm{s} \\
\text { kuan } \mathrm{s}\end{array}$ & $\begin{array}{l}\text { bagia } \\
\text { bagia } \\
\text { bagial }\end{array}$ & & \\
\hline
\end{tabular}

Grafik korelasi persentase sel hidup dengan berbagai waktu inkubasi pada uji doubling time ditunjukkan pada Gambar 2. Gambar 2 menunjukkan bahwa setelah pemberian sampel uji dan pertambahan waktu inkubasi sampai 72 jam tampak terjadi penurunan persentase sel hidup pada berbagai konsentrasi sampel. Pada konsentrasi 50\% serum yang diperlakukan dengan serbuk tokek secara keseluruhan mampu menghambat proliferasi sel kanker kolon WiDr seiring dengan pertambahan waktu inkubasi sampai 72 jam. 


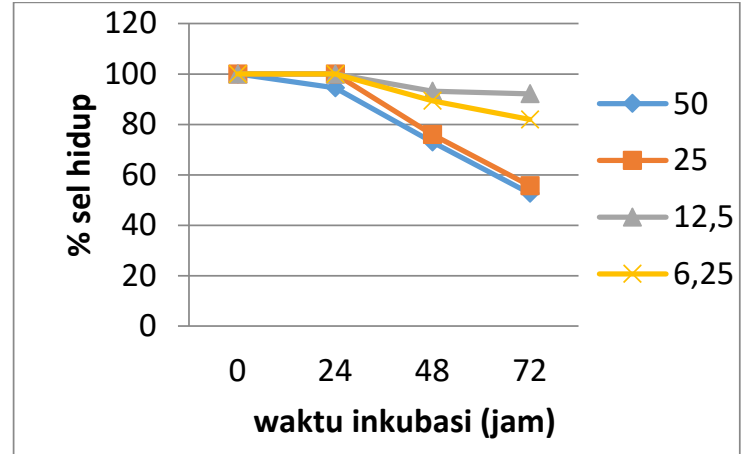

(A)

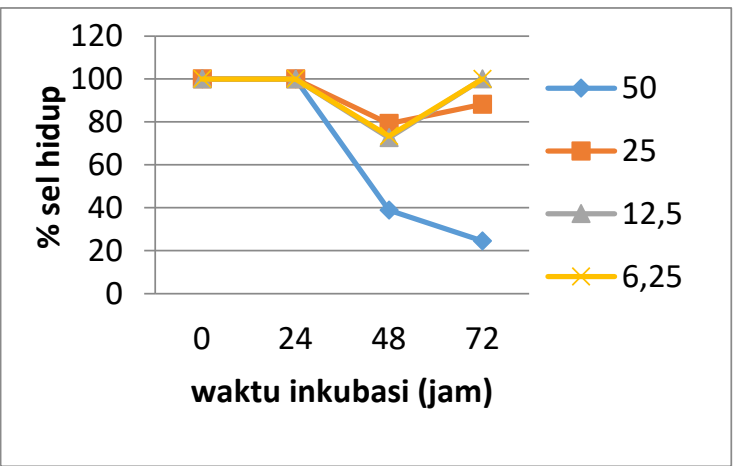

(C)

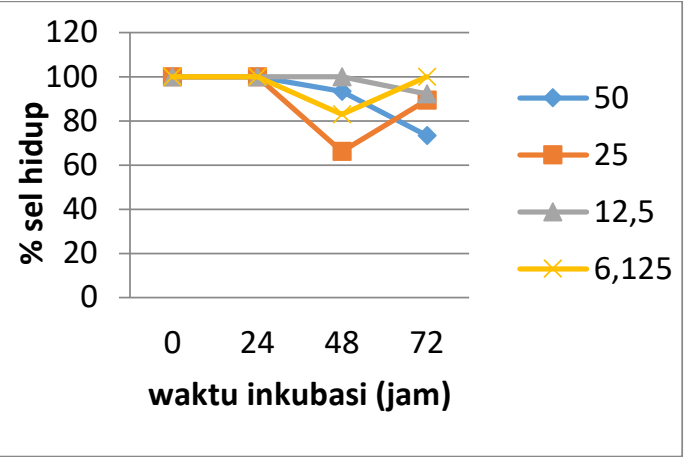

(B)

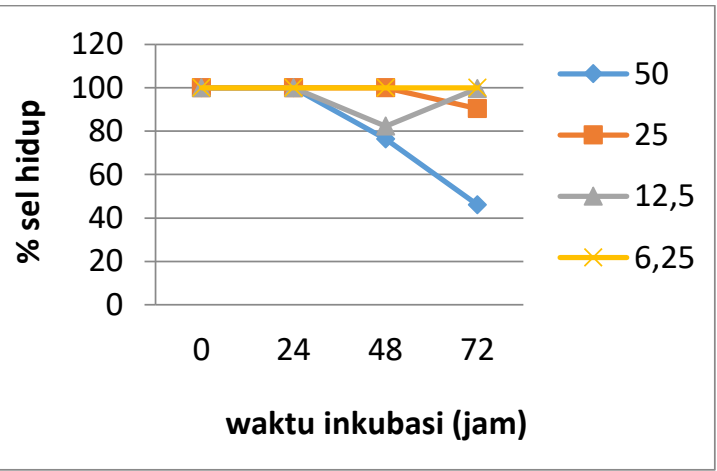

(D)

Gambar 2. Grafik korelasi antara persentase sel hidup sel kanker kolon WiDr dengan berbagai waktu inkubasi hasil uji doubling time, (A) kontrol serum, (B) perlakuan serum tikus yang diberi serbuk tokek bagian kepala, (C) perlakuan serum tikus yang diberi serbuk tokek bagian badan, dan (D) perlakuan serum tikus yang diberi serbuk tokek bagian ekor+tungkai

Kelompok kontrol serum pun juga menunjukkan penghambatan proliferasi sel kanker kolon WiDr dengan pertambahan waktu inkubasi. Slope yang signifikan menunjukkan penghambatan adalah pada P2 yaitu perlakuan serum tikus putih yang diberi perlakuan dengan serbuk tokek bagian badan pada konsentrasi 50\% mampu menghambat proliferasi sel kanker kolon WiDr sebesar 61\% dengan jumlah sel hidup $39 \%$ pada waktu inkubasi 48 jam ditunjukkan pada Gambar 2C. Data persentase jumlah sel kolon WiDr yang hidup dengan perlakuan doxorubicin ujidoubling time dapat dilihat pada Tabel 4.

Tabel 4. Persentase jumlah sel kolon WiDr yang hidup dengan perlakuan doxorubicin uji doubling time

\begin{tabular}{cccccc}
\hline & \multicolumn{5}{c}{ Jumlah sel hidup (\%) } \\
\hline \multicolumn{2}{c}{ Konsentrasi (\%) } & $\mathbf{0}$ & $\mathbf{2 4}$ & $\mathbf{4 8}$ & $\mathbf{7 2}$ \\
\hline Doxorubicin & 6,25 & 100 & 69,48 & 35,83 & 16,54 \\
\hline 3,125 & 100 & 76,94 & 36,50 & 16,10 \\
\hline & 1,5625 & 100 & 100 & 49,45 & 18,84 \\
\hline & 0,78125 & 100 & 100 & 61,97 & 23,52 \\
\hline
\end{tabular}

Pada Tabel 4 dapat dilihat bahwa dengan perlakuan doxorubicin mampu menghambat proliferasi sel kanker kolon WiDr seiring dengan pertambahan waktu inkubasi. Penghambatan terbesar ditunjukkan pada konsentrasi 3,125 $\mu \mathrm{g} / \mathrm{ml}$. Grafik korelasi persentase sel hidup sel kanker kolon WiDr dengan berbagai waktu inkubasi dengan perlakuan doxorubicin pada uji doubling time dapat dilihat pada Gambar 3. 


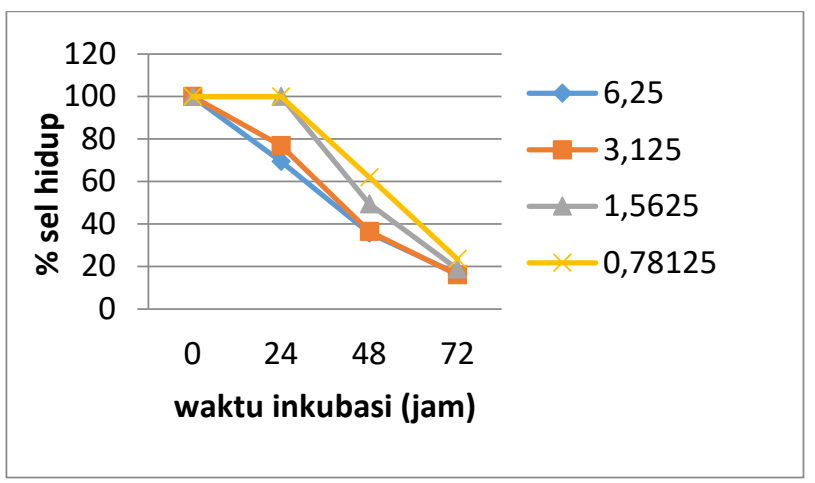

Gambar 3. Grafik korelasi antara persentase sel hidup sel kanker kolon WiDr dengan berbagai waktu inkubasi hasil uji doubling timepada perlakuan doxorubicin

Pada Gambar 3 dapat dilihat bahwa slope yang semakin kecil dengan pertambahan waktu inkubasi dengan perlakuan doxorubicin. Slope yang paling kecil pada perlakuan doxorubicin pada konsentrasi $6,25 \mu \mathrm{g} / \mathrm{ml}$ kemudian disusul 3,125 $\mu \mathrm{g} / \mathrm{ml}, 1,5625 \mu \mathrm{g} / \mathrm{ml}$ dan $0,78125 \mu \mathrm{g} / \mathrm{ml}$.

Efek serbuk tokek terhadap apoptosis sel kanker kolon WiDr. Kematian sel kolon WiDr akibat perlakuan serum tikus yang diberi perlakuan serbuk tokek juga dapat diketahui melalui uji apoptosis. Metode uji apoptosis yang digunakan adalah metode double staining DNA dengan menggunakan ethidium bromideacrydin orange. Konsentrasi sampel yang digunakan untuk uji apoptosis ini adalah $25 \%$ dan untuk konsentrasi doxorubicin 3,125 $\mu \mathrm{g} / \mathrm{ml}$. Kondisi kontrol sel setelah pewarnaan double staining dapat dilihat pada Gambar 4.

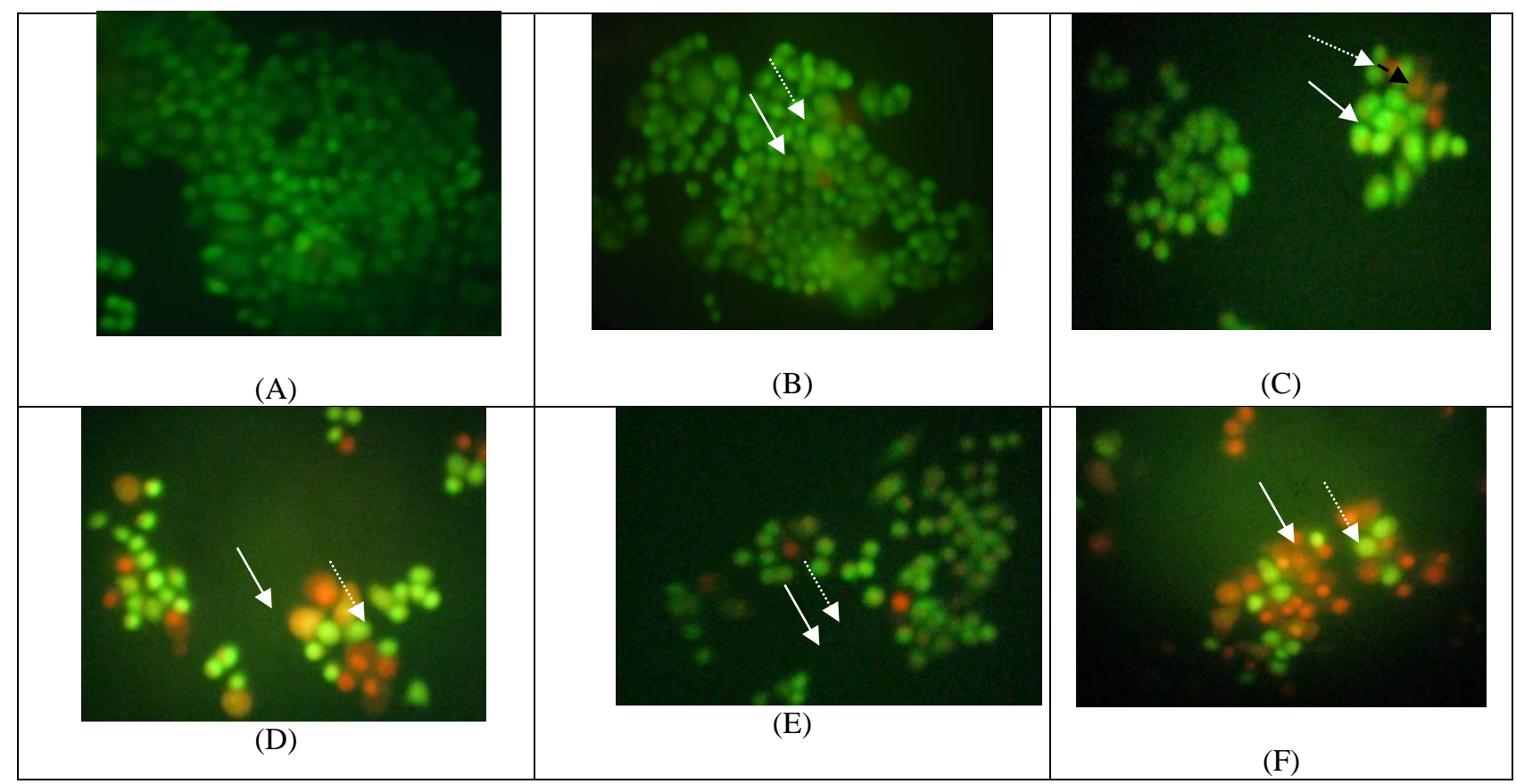

Keterangan : $\longrightarrow$ : sel WiDr yang diduga apoptosis -..- sel WiDr yang hidup

Gambar 4. Kondisi sel setelah pewarnaan dengan ethidium bromide/ akridin oranye pada berbagai perlakuan (A) kontrol sel, (B) kontrol serum, (C) perlakuan serum yang diberi serbuk tokek kepala, (D) perlakuan serum yang diberi serbuk tokek badan, (E) perlakuan serum yang diberi serbuk tokek ekor+tungkai, $(\mathrm{F})$ perlakuan dengan doxorubicin (perbesaran mikroskop 10x10)

Berdasarkan Gambar 4 menunjukkan bahwa sel berfluoresens hijau setelah pewarnaan dengan ethidium bromide/ akridin oranye. Hal ini menunjukkan bahwa sel 
tersebut masih hidup dan tidak mengalami apoptosis. Hasil pengamatan dibawah mikroskop fluorescens memperlihatkan bahwa sel kolon WiDr yang hidup akan berfluoresens hijau dengan akridin orange sedangkan sel yang mati berfluorescens oranye dengan ethidium bromide. Gambar 4A memperlihatkan bahwa sel kanker kolon WiDr yang tidak diberi perlakuan dengan serum tikus terlihat bsel masih hidup. Demikian pula pada Gambar 4B sel kanker kolon WiDr yang diberi kontrol serum tikus putih yang tidak diperlakukan dengan serbuk tokek sebagian sel masih hidup.Namun juga terlihat beberapa sel yang berfluoresens oranye atau sel mengalami apoptosis.Gambar 4C sel kanker kolon WiDr yang diperlakukan dengan serum tikus putih yang diberi serbuk tokek bagian kepala terlihat sebagian besar sel masih hidup tetapi juga tampak sel yang mengalami apoptosis namun dalam jumlah yang sedikit.

Gambar 4D memperlihatkan sel kanker kolon WiDr mengalami apoptosis setelah diberi serum tikus putih yang diperlakukan dengan serbuk tokek bagian badan. Pada Gambar 4D menunjukkan sel mengalami apoptosis jumlahnya cukup banyak dan terdapat pula sel yang masih hidup. Pada perlakuan dengan serum tikus putih yang diberi perlakuan serbuk tokek bagian badan ini terlihat sel lebih banyak yang mengalami apoptosis dibandingkan dengan perlakuan yang lain. Kondisi ini disebabkan karena pada perlakuan serbuk tokek bagian badan menurut Setyawati (2003) mempunyai kandungan protein yang lebih tinggi dibandingkan dengan bagian tubuh tokek yang lain. Menurut Shapiro \& Harper (1999), pemberian senyawa atau protein dapat menghambat proliferasi sel dan memacu apoptosis.

Gambar 4E memperlihatkan sel kanker kolon WiDr yang diberi perlakuan serum tikus putih yang diperlakukan dengan serbuk tokek bagian ekor+tungkai mengalami apoptosis. Pada Gambar 4E menunjukkan sel yang hidup jumlahnya cukup banyak namun terdapat pula sel yang mengalami apoptosis. Pada kontrol positif perlakuan dengan doxorubicin yang ditunjukkan pada Gambar 4F sebagian besar sel juga tampak sel mengalami apoptosis.
Hasil penelitian ini menunjukkan bahwa sampel uji yaitu serum tikus yang diperlakukan dengan serbuk tokek bagian badan bersifat toksik terhadap sel kanker kolon WiDr, juga mampu menghambat proliferasi dan memacu apoptosis sel kanker kolon WiDr. Hal ini disebabkan karena pada serum tersebut mengandung jenis protein tertentu yang mampu mempengaruhi sel kanker kolon WiDr.Penelitian yang dilakukan oleh Wang (2005) menunjukkan bahwa perlakuan dengan serum tikus yang diberi perlakuan dengan ekstrak lebih efektif berpengaruh terhadap subyek uji dibandingkan dengan perlakuan dengan ekstrak secara langsung pada uji in vitro.

Hasil penelitian ini menunjukkan bahwa sampel uji dalam hal ini serum tikus yang diperlakukan dengan serbuk tokek bersifat toksik terhadap sel kanker kolon WiDr, mampu menghambat proliferasi dan memacu apoptosis sel kanker kolon WiDr.

\section{KESIMPULAN}

Dari penelitian yang telah dilakukan dapat dibuat kesimpulan bahwa serum tikus putih yang diberi perlakuan dengan serbuk tokek bagian badan bersifat toksik dan mampu menghambat proliferasi serta memacu apoptosis sel kanker kolon WiDr.

\section{DAFTAR PUSTAKA}

AIHW. 2004. Cancer Facts and Figures, HUhttp://www.wrongdiagnosis.com/c/ colorectal/stats.htm.prevalence and incidence stats $U H$

Liu F, Jian GW, Shu YW, Yan L, Yin PW, Shou MX. 2008. Antitumor Effect and Mechanism of Gecko on Human Esophageal carcinoma Cell lines in vitro and xenografted sarcoma 180 in Kunming mice. Journal of Gastroenterol, 25: 39903996.

Meiyanto E, Ratna AS, Fitria R, Handayani S. 2008.Ekstrak Etanolik Biji Buah Pinang (Areca catechu L.) mampu menghambat proliferasi dan memacu apoptosis sel MCF-7. Majalah Farmasi Indonesia , 19 (1): $21-28$ 
Rang HP, Dole MM, Ritter JM, Moore PK. 2003. Pharmacology. $5^{\text {th }}$ ed. Churchill Livingstone, New York.p.60-77,693-703.

Saputra K. 2003. Manfaat Pengobatan Alternatif Untuk Terapi Kanker, makalah disampaikan pada simposium Obat Herbal dan Akupuntur Estetika pada Era 2003. Perhimpunan Kedokteran Komplementer dan Akupuntur Indonesia (PKKAI). Jakarta.
Shapiro GI, Harper JW. 1999. Anticancer Drug Target: Cell Cycle and Checkpoint Control, J. Clin Invest. 104: 1645-1653

Wang B, Zhu L, Chen Q. 2005. Primary study on the Application of Serum Pharmacology in Chinese Traditional Medicine. Colloids and Surfaces B: Biointerfaces. 43: 194-197. 